\title{
Nowadays COVID underestimates the other suspects
}

\author{
Dorina ESENDAĞLI ${ }^{1}$ (ID) \\ Korhan $\operatorname{TEK}^{2}$ (ID) \\ Gülbahar DARILMAZ \\ YÜCE ${ }^{1}$ (ID) \\ Koray HEKIMOĞLU ${ }^{3}(I D)$ \\ Gaye $\operatorname{ULUBAY}^{\mathbf{1}}$ (ID)
}

Cite this article as: Esendağı D, Tek K, Darılmaz Yüce G, Hekimoğlu K Ulubay G. Nowadays COVID underestimates the other suspects. Tuberk Toraks 2020;68(3):342-345.

Yazışma Adresi (Address for Correspondence)

\section{Dr. Dorina ESENDAĞLI}

Başkent Üniversitesi Tıp Fakültesi, Göğüs Hastalıkları Anabilim Dalı, ANKARA - TÜRKIYE

e-mail: dr.dorina.de@gmail.com

CCopyright 2020 by Tuberculosis and Thorax.

Available on-line at www.tuberktoraks.org.com
${ }^{1}$ Department of Chest Diseases, Faculty of Medicine, Baskent University, Ankara, Turkey

1 Başkent Üniversitesi Tıp Fakültesi, Göğ̈̈s Hastalıkları Anabilim Dalı, Ankara, Türkiye

${ }^{2}$ Department of Internal Diseases, Faculty of Medicine, Baskent University, Ankara, Turkey

${ }^{2}$ Başkent Üniversitesi Tıp Fakültesi, İç Hastalıkları Anabilim Dalı, Ankara, Türkiye

${ }^{3}$ Department of Radiology, Faculty of Medicine, Baskent University, Ankara, Turkey

${ }^{3}$ Başkent Üniversitesi Tıp Fakültesi, Radyoloji Anabilim Dalı, Ankara, Türkiye

\section{ABSTRACT}

Nowadays COVID underestimates the other suspects

The whole world has been facing the pandemic of SARS-CoV-2 infection and every day we still find out new knowledge regarding the disease. COVID-19 which is the name given to the clinical syndrome related to this infection has been shown to own a wide diversity of clinical presentations which challenges the healthcare workers and makes difficult the diagnosis and management of patients. Pulmonary embolism is also an entity that accompanies this type of infection and sometimes it is difficult to differentiate between the two. Here we present a patient who was admitted inward with typical lesions on chest tomography for COVID-19, but that turned out to be a submassive pulmonary embolism case without any infection. This case is remarkable because it shows that patients suspected for COVID-19 should be carefully examined and that pulmonary embolism can per se mimick the parenchymal lesions caused by viral infections.

Key words: Pulmonary embolism; D-dimer; COVID-19; chest tomography

\section{Öz}

\section{Günümüzde COVID diğer tanıları maskeler}

Tüm dünya SARS-CoV-2 enfeksiyonun salgınıyla karşı karşıyadır ve her geçen gün hala hastalıkla ilgili yeni bilgiler öğreniyoruz. Bu enfeksiyonun yol açtığı klinik sendroma verilen isim COVID-19'un, sağlık çalışanlarını zorlayan ve hastaların tanı ve tedavisini zorlaştıran çok çeşitli klinik prezentasyonlara sahip olduğu gösterilmiştir. Pulmoner emboli de bu enfeksiyona eşlik eden bir durum olup bazen ikisini ayırt etmek oldukça zordur. Bu yazıda, toraks tomografisinde COVID-19 için tipik lezyonlarla yatırılan, ancak yapılan tetkiklerin sonucunda herhangi bir enfeksiyon saptanmayan bir submasif pulmoner 
emboli vakası sunuyoruz. Bu vaka dikkat çekicidir çünkü COVID-19 şüphesi olan hastaların dikkatle incelenmesi gerektiğini ve pulmoner embolinin viral enfeksiyonların neden olduğu parankimal lezyonları kendi başına taklit edebileceğini göstermektedir.

Anahtar kelimeler: Pulmoner emboli; D-dimer; COVID-19; toraks tomografisi

\section{INTRODUCTION}

The available literature regarding SARS-CoV2 infection has shown the important role that computed tomography (CT) has in diagnosing infected patients even when real time reverse transcriptase polymerase chain reaction (RT-PCR) is initially negative (1). The accepted and reccommended imaging nowadays is non-contrast CT for cases that have either a relevant clinical presentation or a history of exposure to an infected patient before (2). On the other hand the COVID-19 patients have been reported to be at risk of acute pulmonary embolism due to excess thrombin and reduction of fibrinolysis secondary to endothelial activation induced by the infection (3). D-dimer levels are often elevated in these patients and values higher than $7000 \mathrm{ng} / \mathrm{mL}$ are related with confirmed thromboembolism (4). Here we present a case which had typical lesions in chest CT for
COVID-19, who turned out to be a submassive pulmonary embolism (PE) patient.

\section{CASE REPORT}

A 71 year-old female patient was admitted to the policlinics with cough, dyspnea and back pain for 4 days. Her physical examination showed a reduced oxygen saturation (93\%) with no other abnormal findings. She had a past history of diabetes, hypertension and vertigo. The laboratory results showed elevated white blood cells count $(15.100 / \mathrm{ml})$ and CRP $(62.9 \mathrm{mg} / \mathrm{L})$ with normal liver and kindey function tests. CT of the chest revealed atelectasia and pleura based ground glass opacity at left side with interlobuler septal thickening (Figure 1). The radiological findings were suspicious for COVID-19 and the patient was admitted inward in isolated conditions. RT-PCR for SARS-CoV2 was negative and further lab-
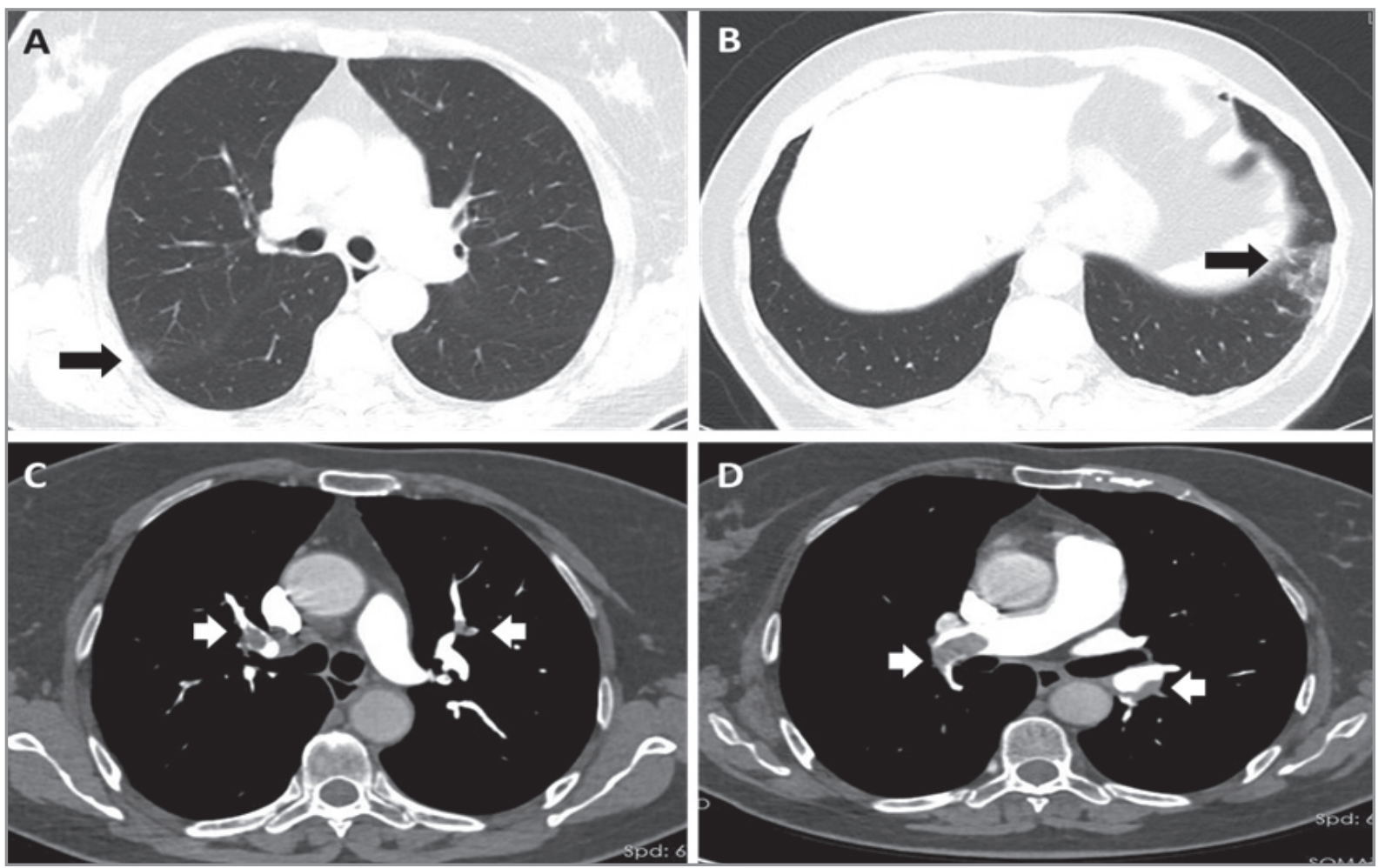

Figure 1. CT of thorax. A and $\mathbf{B}$ showing parenchymal changes resembling COVID-19 pneumonia; $\mathbf{C}$ and $\mathbf{D}$ showing massive acute thrombosis in bilateral pulmonary artery branches. 
oratory examination showed elevated ferritin, troponin and a D-dimer level too high to be detected. Since the patient had a reduced oxygen saturation and a history of sedentary life for the past three months CT angiography of the chest was performed and massive acute thrombosis in bilateral pulmonary artery branches with early stage parenchymal infarct area in the left was detected (Figure 1). A second RT-PCR for SARS-CoV2 was also negative.

Echocardiography performed bedside showed dilated right ventricle and the patient was accepted as a submassive PE case and given tissue plasminogen activator (t-PA) $50 \mathrm{mg} / 2$ hours infusion followed by low-molecular weight heparin. The venous doppler ultrasound for lower extremities was normal and the control echocardiography at third day of treatment showed normal right ventricle and a pulmonary artery pressure of $35 \mathrm{mmHg}$. The patients oxygenation was improved (96\%) and she was discharged with oral anticoagulation.

\section{DISCUSSION}

SARS-CoV2 pandemics which is still ongoing and already spread throughout all over the world leads clinicians to approach every single patient with pulmonary or flu-like symptoms as a possible infected case. Non-contrast chest CT is a widely used technique to detect early lung lesions and make the differential diagnosis even when RT-PCR is negative $(1,2)$. On the other hand COVID-19 is characterized by coagulation activation and endothelial dysfunction which leads to pulmonary embolism in 23-27\% of patients especially if they are hospitalized (4-6). Here we presented a PE case which was initially thought to be a COVID-19 pneumonia because the typical lesions in chest CT. The approach with non-contrast CT in these patients with high probability of thrombosis leads to repeated tomographies and sometimes delay of diagnosis. The high D-dimer level was the laboratory parameter which lead to further investigation with pulmonary angiography and bilateral massive thrombosis was detected. In suspicious cases for COVID-19 performing a D-dimer test before CT might reduce the repeated radiological tests and also the amount of radiation that the patient receives. There is no clear cut-off, but values of D-dimer higher than $7000 \mathrm{ng} / \mathrm{mL}$ are shown to be related with PE and this might suggest to perform a contrast CT from the start (4). The patient had 2 RT-PCR results negative for SARS-CoV2 and since the parenchymal changes were typical one might think that this case can still be a COVID-19 patient as PCR results either may be negative due to the kit/technique used or because the patients can be PCR negative at first (7). The dramatical recovery after tPA infusion which improved the clinical presentation of the patient by normalizing the oxygen saturation and the echocardiography findings with absence of any symptom or further laboratory findings related to infection suggests that this was a submassive pulmonary case and not a COVID-19 one.

Pulmonary embolism is closely related with COVID19 and patients present with similiar symptoms and findings in both diseases and sometimes the two are detected simultaneously. Anticoagulation is recommended to COVID-19 patients and this might also help for undiagnosed PE cases initially when non contrast CT is performed (8).

\section{CONFLICT of INTEREST}

The authors reported no conflict of interest related to this article.

\section{AUTHORSHIP CONTRIBUTIONS}

\section{Concept/Design: DE}

Analysis/Interpretation: DE, KH

Data Acquisition: KT, GDY

Writting: DE

Critical Revision: GU

Final Approval: All of authors

\section{REFERENCES}

1. Rotzinger DC, Beigelman-Aubry C, von Garnier C, Qanadli SD. Pulmonary embolism in patients with COVID-19: time to change the paradigm of computed tomography. Thromb Res 2020; 190: 58-9.

2. Chen, HJ, Qiu, J, Wu B, et al. Early chest CT features of patients with 2019 novel coronavirus (COVID-19) pneumonia: relationship to diagnosis and prognosis. Eur Radiol 2020; 1-8.

3. Marchandot B, Sattler L, Jesel L, COVID-19 Related Coagulopathy: A distinct entity?. J Clin Med 2020; 9(6): 1651 .

4. Grillet F, Behr J, Calame P, Aubry S, Delabrousse E. Acute pulmonary embolism associated with COVID-19 pneumonia detected by pulmonary CT angiography. Radiol 2020; 23: 201544

5. Chen J, Wang X, Zhang S, et al. Findings of acute pulmonary embolism in COVID-19 patients. Available at: SSRN 3548771. 2020 
6. Klok FA, Kruip MJHA, van der Meer NJM, et al. Incidence of thrombotic complications in critically ill ICU patients with COVID-19. Thromb Res 2020; 191: 145-7.

7. Kucirka LM, Lauer SA, Laeyendecker O, Boon D, Lessler J. Variation in false-negative rate of reverse transcriptase polymerase chain reaction-based SARS-CoV-2 tests by time since exposure. Ann Intern Med 2020; 173(4): 262-7.
8. Barnes, GD, Burnett A, Allen A, et al. Thromboembolism and anticoagulant therapy during the COVID-19 pandemic: interim clinical guidance from the anticoagulation forum. J Thromb Thrombolysis 2020; 50(1): 72-81. 